THE INDUSTRIAL REVOLUTION 
Also by Douglas Fisher

MACROECONOMIC THEORY

MONETARY AND FISCAL POLICY

MONETARY POLICY 


\section{The Industrial Revolution}

A Macroeconomic Interpretation

Douglas Fisher

Professor of Economics

North Carolina State University

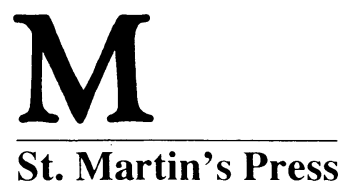


All rights reserved. No reproduction, copy or transmission of this publication may be made without written permission.

No paragraph of this publication may be reproduced, copied or transmitted save with written permission or in accordance with the provisions of the Copyright, Designs and Patents Act 1988, or under the terms of any licence permitting limited copying issued by the Copyright Licensing Agency, 90 Tottenham Court Road, London WIP 9HE.

Any person who does any unauthorised act in relation to this publication may be liable to criminal prosecution and civil claims for damages.

First edition 1992

Reprinted 1993, 1994

Published in Great Britain by

THE MACMILLAN PRESS LTD

Houndmills, Basingstoke, Hampshire RG21 2XS

and London

Companies and representatives

throughout the world

A catalogue record for this book is available from the British Library.

ISBN 978-0-333-61114-2 ISBN 978-1-349-13445-8 (eBook)

DOI 10.1007/978-1-349-13445-8

First published in the United States of America 1992 by

Scholarly and Reference Division,

ST. MARTIN'S PRESS, INC.,

175 Fifth Avenue,

New York, N.Y. 10010

ISBN 978-0-312-07989-5 (cloth)

ISBN 978-0-312-10366-8 (paper)

Library of Congress Cataloging-in-Publication Data

Fisher, Douglas, 1934-

The Industrial Revolution : a macroeconomic interpretation /

Douglas Fisher.

p. $\mathrm{cm}$.

"First published in Great Britain 1992 by The Macmillan Press

Ltd"-Verso t.p.

Includes bibliographical references (p. ) and index.

ISBN 978-0-312-07989-5 (cloth) - ISBN 978-0-312-10366-8 (paper)

1. Europe-Economic conditions-18th century. 2. Europe-Economic

conditions-19th century. 3. Europe-Industries-History.

I. Title.

HC240.F48 1992

$338.094-\mathrm{dc} 20$ 
To Ann and Henry 


\section{Contents}

Preface

1 The Background to the British Industrial Revolution 1

$\begin{array}{lll}1.1 & \text { Introduction } & 1\end{array}$

1.2 Population dynamics before the industrial revolution

1.3 The growth of agricultural output in England, $1700-1800$

1.4 English industrialization prior to the revolution 10

1.5 British national income in the 18th century 17

1.6 Wages, profits and interest 25

1.7 The 18th-century business cycle (to 1780) 35

1.8 Conclusion 40

2 The First Industrial Revolution in Britain, 1780-1860: National Income and Its Distribution

2.1 Introduction $\quad 42$

2.2 Population and agriculture: brief notes 43

2.3 British industrialization 46

2.4 Economic growth during the industrial revolution $\quad 49$

2.5 The components of national product 52

2.6 British business cycles 64

2.7 The standard-of-living debate: macro issues 71

2.8 Conclusion $\quad 78$

3 The United Kingdom in the Second Half of the 19th Century: Maturity and Relative Decline

3.1 Introduction $\quad 80$

3.2 The growth of the British macroeconomy,
1850-1910

3.3 Some time-series properties of the income data 87

3.4 Business cycles in the Victorian and Edwardian economy $\quad 91$

3.5 The UK financial sector 102 
3.6 Interaction across the Atlantic

4 Industrialization without Revolution: the French Case

4.1 Introduction

4.2 The background to French industrialization

4.3 The industrialization of the French economy

4.4 France's macroeconomy in the 19th century

4.5 The quantity theory of money in 19th-century France

\subsection{Conclusion}

5 The Development of the German Macroeconomy

5.1 Introduction

5.2 The background to German industrial growth

5.3 The development of the aggregate economy in Germany after 1850

5.4 The role of money in the German expansion

5.5 Conclusion

6 Sweden during the Industrial Revolution

6.1 Introduction

6.2 The background to modern growth in Sweden

6.3 Sweden's take-off; macroeconomic aspects

6.4 Sweden's financial sophistication in the 19th century

6.5 Conclusion

7 Italy at the Time of the Industrial Revolution 224

7.1 Introduction 224

7.2 Italian industrialization: background and growth 229

7.3 The Italian macroeconomy in the late 19th century 235

7.4 Money and the Italian economy 239

7.5 Conclusion 251

8 The European Macroeconomy 253

8.1 Introduction 253

8.2 A summary of European growth statistics 254 
8.3 Monelary interaction in the late 19th century 259

8.4 Neutrality in the late 19th century 266

8.5 The Pan-European business cycle 269

8.6 Conclusion 279

End notes $\quad 281$

Bibliography $\quad 299$

Index 309 


\section{Preface}

This is a study of the European macroeconomy covering the period 1700 to 1910 . There are two broad themes of this study, one involving the techniques of analysis and one involving the nature of the European economy itself. The methods of analysis feature techniques drawn from the time-series toolkit of the modern macroeconomist; this involves Granger-causality and unit root tests, although there are also other sorts of structural and specification tests and (even) several cases when a simultaneous-equations system is employed. With regard to the economics, quite simply put, the sustaining argument is the notion that much of Western Europe shares many of the economic processes at work over this period, speaking quite generally of course. In particular, we will be arguing that all of the countries in our sample are drawing at least some resources from a common pool and that certainly by 1700 or so positive per capita economic growth is the normal state of affairs in at least the most highly-developed parts of most of these countries. Here local conditions (soil, population dynamics, etc.) and events (weather, wars, revolutions, and the like), configure the actual rate of growth in particular countries. At the other end of the period (in 1910), on the other hand, all of these countries have clearly experienced an industrial transformation whose overall style is remarkably similar.

With regard to our emphasis on macroeconomics it should be pointed out that much of the material of economic history actually refers to economic aggregates - to inflation rates, the rate of growth of GNP, unemployment, the balance of payments, and the functional distribution of income - but in the historical literature less use is made of formal macroeconomic theory (or of its associated econometrics)' than is possible, or so it seems to this writer. In the first instance this simply involves the use of standard macro-static and macro-dynamic reasoning, but at a deeper level it involves the struggle to demonstrate the identification and stability of economic relationships, and to establish the direction of causation among economic variables. These concerns are shared by all economists, whatever their interests, but it is notable that in the historical literature formal treatment of these topics rarely occurs, even though identification, stability and, especially, causation are often claimed for particular hypotheses. At any rate, in this study we shall try to be 
considerably more self-conscious about these matters, at least insofar as the data will bear the weight of our techniques.

In this study we will advance the proposition that growth and penetration is widely spread across Western Europe - although it clearly does not touch all parts of all countries equally - and that depending critically on local circumstances, the growth prior to and during the industrial revolution is a shared one. The industrial revolution did not arrive just in England alone in the 18th century, although there the conditions were certainly most appropriate and the developments most obvious, but all over the Continent as well, although local conditions give a significantly different twist to the story, as it unfolds. This hypothesis, then, downplays individual differences, particularly as they involve nationalities, and argues that a good approximation is that the industrial revolution was shared over much of Western Europe, arriving and conquering in a remarkably short time on a broad front.

To be a shade too specific, it is as if there were at the time a de facto 'common market' in Western Europe, involving England, Northern France, much of Holland, Belgium and parts of Western Germany and Northern Italy in the first instance, and much of the rest of Europe by 1910 . Basic to our purpose, then, is to generate quantitative material describing how this common area developed and how it divided up its economic tasks, from data that are predominantly national in their scope.

The reader should probably think of the current study as a first pass at the problems just described. For one thing, the data are not sufficient to do much more than discuss the general case until just after the Napoleonic wars. We can get pretty far with the British data in the 18th century, and this is actually convenient (if a little misleading) in that much of the literature takes this line. Furthermore, it is certainly economical of the space in this study to use the British as the general case and the rest of Europe as examples of one thing or another. But we want to emphasize that whether or not the British experience is a good model for other countries is currently being debated and we are not taking a stand on that issue. Even when the data exist for other countries on an annual basis, usually after 1860 or so, they are generally of dubious quality for the sorts of sensitive tests that are employed here. Thus the reader is warned here, and repeatedly below, that he will be looking at the results of specific tests on specific data and that the stated results are conditional. 
We also need to sound a warning about the techniques themselves. There is a certain amount of controversy surrounding the use of Granger-causality and unit-root tests and, for that matter, about the use of correlation and regression analysis. Part of the problem has to do with the weakness of the data (for example, certain testprocedures require longer runs of data than are available). Also important is the concern with tests such as the Granger-causality procedure that establish a kind of proximate causation (really a temporal ordering) but do not provide any information on how important the relationship is. To be sure, there are structural tests offered here, but in many cases, most especially in the tests for monetary neutrality, the Granger-causal influence is all that appears. This has to be taken as a piece of the puzzle: if some Granger-causal link has been established then that is an interesting observation; there are other steps to be taken (empirically), but these are not always on the agenda for this study. Finally, we should note that the regression methods employed here, whether the test is unit-root, Grangercausality or just linear multiple regression, are vulnerable to the claim that there are omitted variables of importance. This is readily admitted, of course, and the author welcomes correspondence on this (and on any other aspect of this study that troubles or interests the reader).

There is one final topic that ought to be addressed here and then neglected for the rest of the book. This is the question of whether we ought to be using the term 'industrial revolution' to describe the transformation of one or more of the countries studied. Over the 210-year period that we are considering, each of these countries went from a predominantly agricultural economy to one that was either predominantly industrial or soon to be. Two hundred years is a short time. Part of the heat in the long debate over this process is related to the notion that without a very rapid transformation - over a generation at most - the change is just not revolutionary. This position gets mixed up with the recent downgrading of the rate of change of industrial activity during Britain's industrial revolution; if Britain did not have an industrial revolution, then nobody did. What is proposed here is to ignore the debate in favour of merely describing the situation; when the term 'industrial revolution' appears in this study, it is used as evocative language, not as an apparent claim that a revolution has occurred.

I wish to thank Lee A. Craig and Walter N. Thurman who were my 
collaborators in several earlier projects that are summarized here. Lee Craig has also read substantial parts of the manuscript and I have profited enormously from his advice. Several of the component pieces have also been read to the members of the Triangle Economic History Workshop and I am grateful to the members of that group for their many comments.

DOUGLAS FISHER 